\title{
Mobile dunes and eroding salt marshes
}

\author{
R. Neuhaus \\ Botanisches Institut der Christian-Albrechts-Universität Kiel; Olshausenstr. 40-60, \\ D-24098 Kiel, Federal Republic of Germany
}

\begin{abstract}
The paper deals with general outlines of salt marsh and dune vegetation in the Ellenbogen and Listland area on Sylt (Schleswig-Holstein, FRG). The composition of current salt marsh vegetation is considered to be mainly the result of a long-lasting process of tidal inundation, grazing, and a permanent influence of groundwater seepage from the surrounding dunes. The lower salt marsh communities have shown constancy for 67 years, due to the effect of heavy grazing. The mid-upper salt marsh communities demonstrated a succession from a Puccinellia maritima-dominated community of the lower marsh to a Juncus gerardii-dominated community of the mid-upper salt marsh, which may be due to the transport of sand - over a short time - on the surface of the marsh. The area covered by plant communities of annuals below Mean High Water (MHW) seemed to diminish. Salt marsh soils, especially of the mid-upper marsh, indicate sandy layers resulting from sand drift of the dunes. Dry and wet successional series of the dunes in the Listland/Ellenbogen area both show grassy stages shifting to dwarf shrubs as final stages. White primary dunes can only be found on the accreting shoreline of the Ellenbogen, which is also grazed by sheep; vegetation cover therefore remains dominated by grasses, mosses and lichens. Three mobile dunes (as the most prominent features of this landscape) have been left unaffected by seeding and planting by local authorities. Grazing is considered to be an inadequate tool in nature conservation as long as natural processes are to prevail in the landscape as major determinants.
\end{abstract}

\section{INTRODUCTION}

Sylt is part of a chain of islands forming the western borderline of the Wadden Sea. It has four major moraine remnants of the Saale/Warthe glaciation which build up the centre of the island (Fig. 1). Most settlements (eight villages out of eleven) lie on the higher moraines, which are surrounded by embanked salt marshes. They build the island's centre part, which developed in the shelter of the largest western moraine block. Sandy beach ridges covered with dunes stretch from this centre to the north and south. The total length of the island is approximately $40 \mathrm{~km}$, and is still changing.

The west coast of Sylt is cut back every year during periods of high storm activity (usually in January and February). The sheltered east coast of the ridges, however, is formed by a small fringe of often terraced salt or brackish marshes, and also dunes. Minor parts of the salt marshes are still growing. Sandy marshes can be found in the lee of dunes on the sand ridges - whereas clayey marshes lie in the vicinity of the moraines.

The Ellenbogen/Listland area, which embraces Königshafen, forms the island's northernmost spit of land (Fig. 3). The Ellenbogen peninsula, elongating from west to east, was formed by strong currents in the "Lister Tief" reshaping the main sand transport direction from the north to the east. The entire Ellenbogen/Listland area is free 


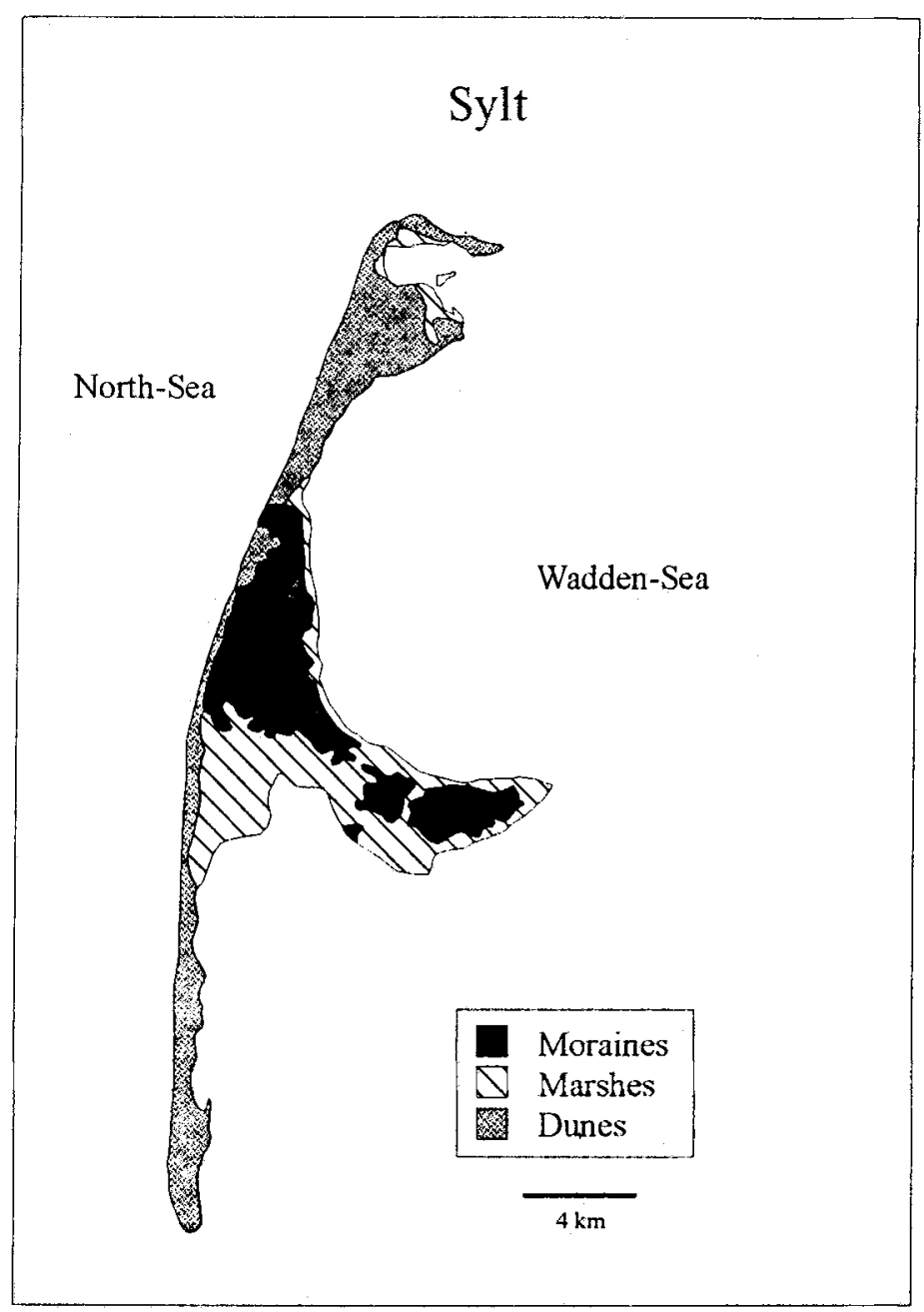

Fig. 1. Distribution of dunes, marshes and moraines on Sylt, adapted from Reichstein (1990)

from moraine remnants at the surface. Area expanse, wilderness, and the various stages of heath formation which are partly reversed by mobile dunes are outstanding features of our coastline (e.g. Buchwald, 1966).

\section{LANDSCAPE HISTORY}

The transgression of the North Sea has led to erosion and reshaping of coastlines after the last glaciation. The moving coastline with its dunes and salt marshes reached the then non-existent island of Sylt approximately 1000 AD (Bantelmann, 1966). Thus, main periods of sand drift in historical times are dated from the 10th, and the 14th-15th centuries (e.g. Müller \& Fischer, 1956; Doody \& Skarregaard, 1991). Fischer (1955) 


\section{Listland and Ellenbogen}
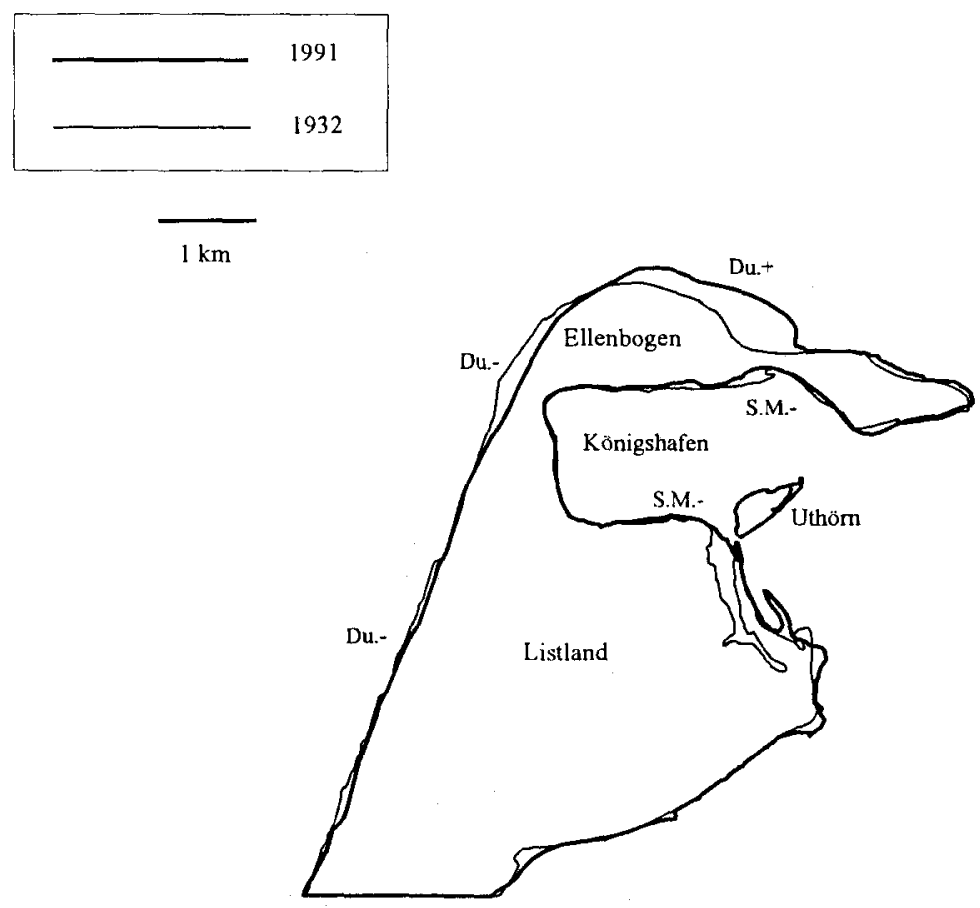

Fig. 2. Comparison of the shorelines from 1932 and 1991. "S. M." and "Du" with a "+" or " - " refer to presumed gains and losses in salt marsh (S. M.) and dune areas (Du)

reported that a combination of sea-level rise and numerous storm tides slowly enlarged tide channels reaching into the hinterland, which started about 500 AD (Bantelmann, 1966). Consequently, land losses also increased slowly, but had two major floodings in the 15 th and 17 th centuries.

At that time, the catchment area of the "Lister Tief" must have been suddenly enlarged - with the consequence of increased sediment transport into the tidal basin, as well as out of it. Major landscape forming may thus be related to the period of the 14th-17th centuries (Christiansen, 1923).

Besides endeavouring to give an outline of sediment budgets in geologic/geomorphologic research, this study illustrates the reshaping of the coastline between 1932 and 1991. Topographical maps $(1: 25000)$ were, for this reason, digitized and drawn as two 


\section{Listland and Ellenbogen}

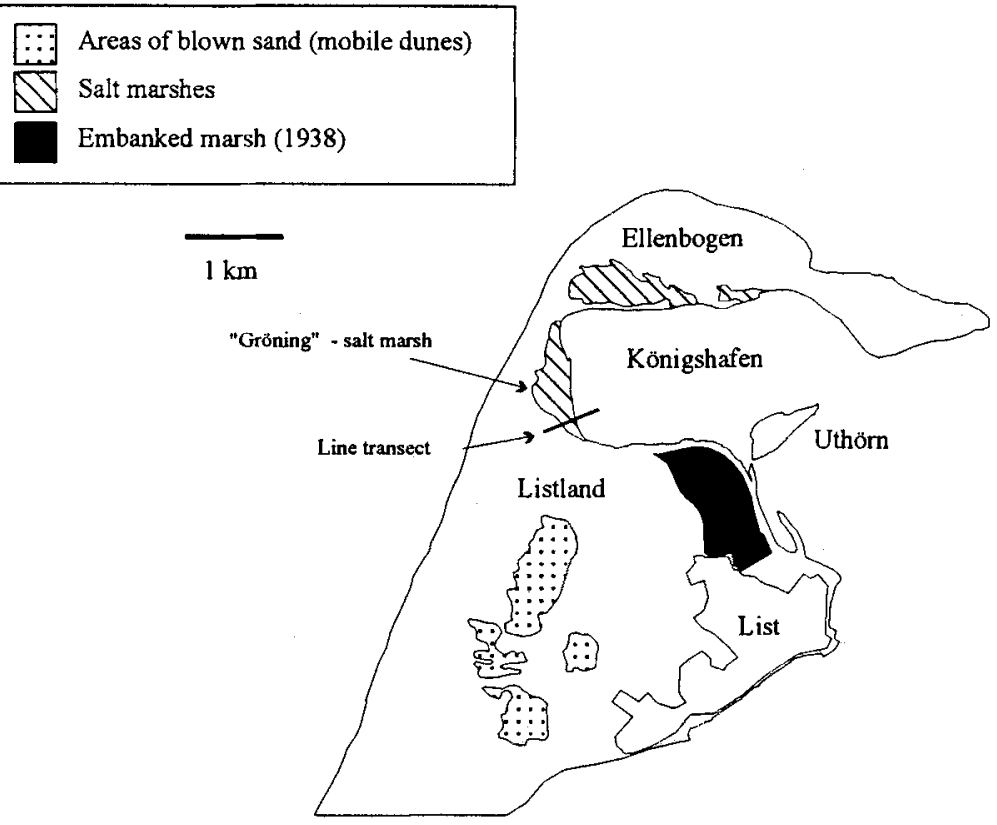

Fig. 3. Salt marshes are located at the inner part of Königshafen; mobile dunes lie in the centre of Listland, heading north-east

layers (Fig. 2). The earlier map was drawn by means of aerial survey in 1932, and is comparable to the recent one.

The MHW line might not be identical, but there is no quantitative evaluation of gains and losses based on this compilation, and errors are not so marked that major trends in the figure could be misinterpreted.

The entire west coast of the Listland had losses of appr. $2 \mathrm{~m} / \mathrm{a}$, which means a total of $118 \mathrm{~m}$ for that time span (ALW, unpubl. report, in Ahrendt, 1993). Major gains of appr. $200 \mathrm{~m}$ can be seen at the northern shoreline (Straka \& Straka, 1984).

The salt marshes inside Königshafen have been eroded, forming microcliffs at the southern shoreline of the Ellenbogen and the northern shoreline of the Listland (see "S. M.-" or "+", Fig. 2). The innermost part called "Gröning" seemed to have been left 
unaffected besides minor losses. The distribution of salt marshes, and areas of blown sand which are roughly identical with mobile dunes can be seen above (Fig. 3).

\section{SALT MARSHES}

With the help of current typification schemes, the marsh can be classified as a "sand beach" (Chapman, 1976), as a "beach plain" (Beeftink, 1977) or, more suitably, as a barrier-connected salt marsh (Dijkema, 1987). These marshes develop at the lee side of dune covered spits, and the soils mainly consist of sand with thin clay layers. Transitions to the dunes are described to be species rich. Nomenclature of species and communities follows Oberdorfer (1983) and Dierßen (1988).

\section{Communities of the lower marsh}

The salt marsh arises from sand flats of Königshafen, with a small Salicornia spp. belt below the MHW line. Creek benches are partly covered with Salicornia-communities: the Salicornietum strictae Christiansen 1927 and the Salicornietum decumbentis Schwabe u. Tx. 1974 (Tuisel, 1983). The latter type had been reported by Nienburg (1927) and Tuisel (1983) as a belt of 1-12 $\mathrm{m}$ at the sea side of the marsh - but was narrower than this in 1993.

The Puccinellietum maritimae Christiansen 1927 dominates the zone behind a small sandy shore (Fig. 4). The elevation in this area increases significantly with a very small terrace. At the southern borderline of Königshafen a microcliff - at the northern line, sand bars or dunes - separate parts of the marsh from the shore.

The Puccinellietum covers the lower-lying, southern part of the central marsh called "Gröning" (Figs 3, 4). The above-mentioned associations are combined into a Puccinellia-Salicornia community ( $=$ lower salt marsh) in the map, for reasons of scale. It comprises three lower marsh communities of the Königshafen area mentioned above.

Low species numbers in the Puccinellietum (3-6 species/relevee) can generally be explained by heavy sheep grazing. Communities on the mainland with comparable grazing intensity also indicate low species numbers, with 3-8 species/sample (e.g. Raabe, 1981). If the Puccinellietum remains ungrazed, average species numbers rise to 8,9 or 10 species (Raabe, 1981; Scherfóse, 1986; von Glahn et al., 1989). A different, species-poor variant of the Puccinellietum is considered to be a substitute for the Halimionetum when grazing pressure is too high (Raabe, 1981).

Cyanobacteria fill the gaps left by the plants, something that had already been observed by Nienburg (1927). Conditions for a Puccinellietum on the "Gröning" are favourable. Puccinellia maritima is partly adapted to waterlogging or flooding (Gray \& Scott, 1977; Cooper, 1982; Armstrong et al., 1985). Results from Cooper (1982) and Van Diggelen (1988) indicate that the growth of Puccinellia maritima is stimulated under nonsaline, waterlogged conditions, which may partly prevail in these soils (Table 1).

Aster tripolium, Halimione portulacoides, Suaeda maritima, Spartina anglica and Limonium vulgare are almost absent from the lower marsh. Aster tripolium, Halimione portulacoides, and Limonium vulgare are susceptible to grazing and trampling (Jensen 1985). In particular, Aster tripolium is fast consumed (Beeftink, 1977) as it is not sheltered by means of structural components, like a high content of crude fibre, prickle cells or a 


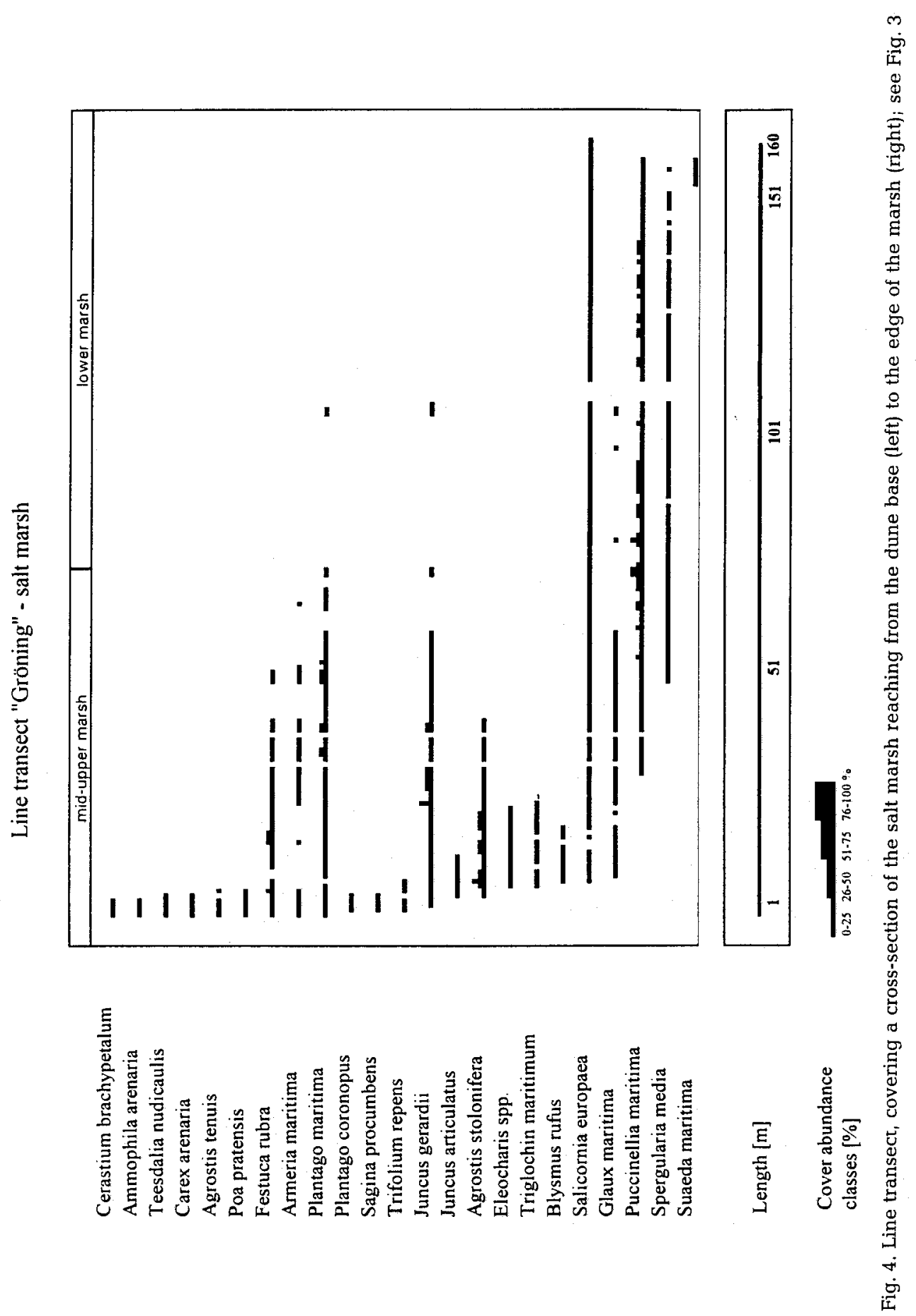


bad smell/taste. Susceptibility of these species can be inferred from the literature in general, as a recovery of all species was reported, after the cessation of grazing (e.g. Bakker \& Ruyter, 1981; Jensen, 1985; Körber \& Neuhaus, unpubl. report; Dierßen et al., unpubl. report).

Spartina anglica has very few occurrences below MHW. It is able to migrate into the lower marsh, especially into salt pans or minor creeks, if grazing is not too heavy and soil conditions are favourable (Körber \& Neuhaus, unpubl. report). Limonium vulgare, a species from the lower and middle marsh, was reported for this area by Wohlenberg (1937). Straka \& Straka (1984) and Tuisel (1983) found the species to be absent: something, which has not altered in 1993.

\section{Communities of the mid-upper marsh}

The transition to the also heavily-grazed Juncetum gerardii (Warming 1906) Nordhagen 1923 is first indicated by Plantago maritima, then completed by Juncus gerardii, Glaux maritima, Festuca ruba and Armeria maritima (Fig. 4). Due to contacts with various terrestrial communities, the Juncetum has a greater floristic and ecological range (Beeftink, 1977; Dierßen, 1988). Thus, Tuisel (1983) reported variants with Salicornia ramosissima, Eleocharis uniglumis, Eleocharis quinqueflora, Carex oederi and a "sandy type" for "Königshafen". Other grazing-intolerant communities of the Armerion are missing (DierBen, 1988).

In the mid-upper marsh the constant occurrence of Salicornia europaea still indicates heavy grazing "at the seaward side" of the community (Fig. 4). Eleocharis uniglumis, Eleocharis quinqueflora and Carex oederi, however, indicate an increasing groundwater contact at the "dune-side". They can also be found in adjacent dune slacks. Small patches of the Blysmetum rufi Gillner 1960 can be found in places where the impact of seepage is considered to be stronger.

\section{THE INFLUENCE OF GRAZING}

Grazing is a common use of salt marshes in northern Europe (Dijkema et al., 1984). The salt marshes in the Listland area have been used for grazing and hay making for at least three centuries (Diedrichsen, pers. comm.; Petersen, unpubl. report). Summer grazing of the salt marshes combined with hay making and winter grazing of local dunes (Ellenbogen, Mövenberg) were common practices. Sheep clearly outnumbered domestic geese, cattle and horses - as the latter needed more care in winter.

The "numerical" grazing intensity is low for the dunes, with $0.4-0.7$ sheep/ha and medium to high for the salt marshes with $3.6-6.8$ sheep/ha. The real intensity is in fact higher in parts of the dunes (and therefore lower in others), as sheep use to graze in favoured areas. Sheep numbers ranged from 600 in 1845 , to 1100 in 1900 , to about 800 today. Especially during the First and Second World Wars, numbers decreased to $1 / 6$ of the aforementioned size (Petersen, unpubl. report). Grazing is likely to control the diversity of vegetation. The correlation is negative in the lower marsh and positive in the middle and higher marshes (Dijkema et al., 1984; Adam, 1990). Results of Tuisel (1983) support this view, as the communities of the Armerion demonstrate a high species 
diversity ( $\alpha$-diversity). On the contrary, $\beta$-diversity probably increases without grazing (Bakker \& Ruyter, 1981).

\section{Succession}

Besides the strong influence on species richness, grazing has an influence on species composition, as it controls salt marsh succession by arresting it in intermediate stages (Jensen et al., 1990). Raabe (1965) could prove this to be the case for Festuca rubra swards in Baltic marshes, where glycophytic perennials could establish and spread after the cessation of grazing. Westhoff (1987) documented a period of 40 years where the Puccinellietum maritimae and Juncetum gerardii of the lower and middle-high marsh were preserved by grazing on Dutch Wadden Sea islands. A (successional) release and rapid spreading of Festuca rubra, followed by invasion of Elymus-species, was documented by Neuhaus \& Grein (unpubl. report; see Fig. 5). The successional step must have been prevented for a long time and immediately before release - judging by this strong "outburst". The adjacent plots showed a similar development.

Succession in the Dollart-estuary, where brackish marshes were abandoned 40 years ago, led to Phragmites-dominated vegetation (Esselink, pers. comm.), and communities of Elymus repens and Festuca rubra became more abundant, over a short time, after 8 years (Jong et al., 1993).

Succession in the lower salt marsh called "Gröning" made rapid steps from initial to building/mature phase from 1924 to 1926 . This was observed by Nienburg (1927), who did not refer to possible causes - like occasional sand drift from the dunes, which can be inferred from sandy layers in the soil. Shapes and transitions between high and low

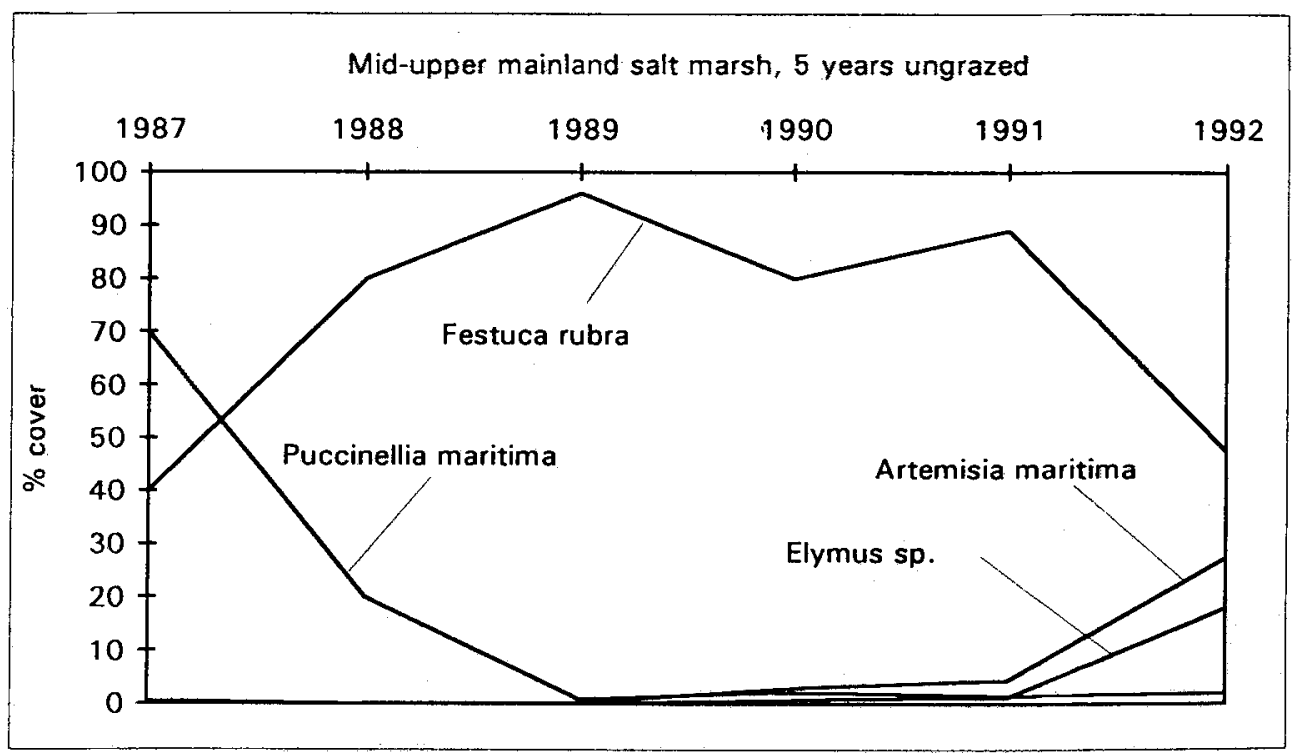

Fig. 5. Succession in a mid-upper salt marsh exclosure in the Sönke-Nissen-Koog salt marshes on the mainland. Festuca rubra shows a strong dominance for 3 years. In the fifth year Elymus sp. invades, introducing the next successional stage 
(open/closed) Puccinellia swards at that time have now been taken by the Juncetum and Puccinellietum (Fig. 6).

The map of Nienburg (1927) has to be interpreted as a scheme for the distribution of vegetation types. Assuming that the descriptions of vegetation types are roughly comparable, because Nienburg (1927) used dominants determined by visual impression, the type and location of the lower salt marsh in the "Gröning" have not changed significantly to this day (in 67 years). Grazing and a high ground water table (waterlogging) have favoured the dominance of Puccinellia maritima.

Abandoning the Königshafen salt marshes would result in a dramatic species exchange. Soil characteristics (Table 1), and the occurrence of species like Carex nigra (no occurrence in line transect, Fig. 4), Carex oederi, Blysmus rufus, Eleocharis spp. and Juncus articulatus, in the upper marsh, indicate high groundwater seepage from the surrounding dunes. This may result in a facilitation for Phragmites australis and wet heath species to invade the mid-upper marsh, as seen elsewhere in marshes on Sylt. The salt marsh would be more and more restricted to a small, outer fringe. After an unknown

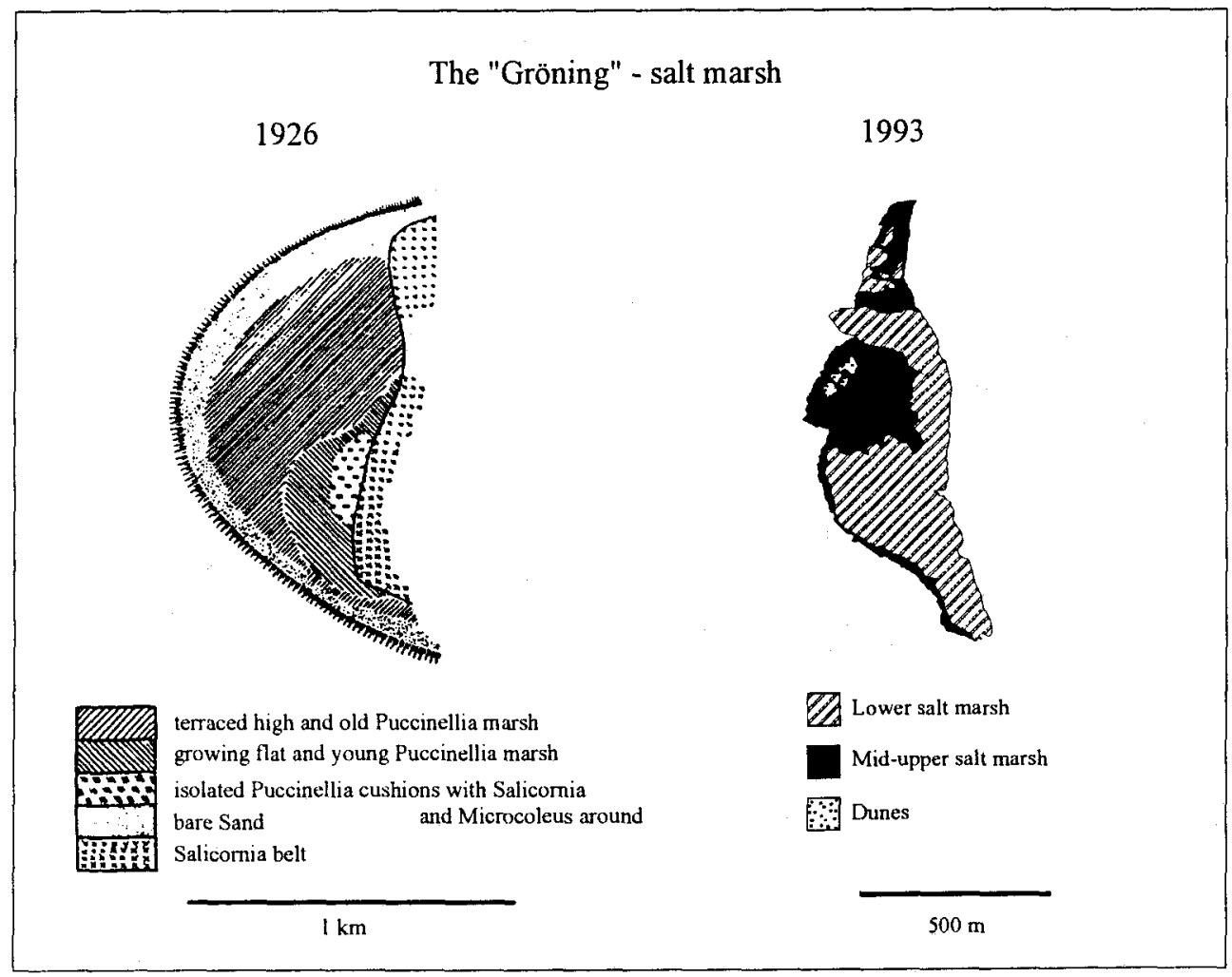

Fig. 6. Over 67 years the "Gröning"-salt marsh has shifted from "old high Puccinellia meadow", as Nienburg (1927) called his plant community, to a mid-upper marsh dominated by Juncus gerardii in its higher parts. The lower marsh remained constant. The location of the "Gröning" salt marsh can be seen in Fig. 3 
period of time - Bakker (1990) gives a period of 10-20 years for major changes - even the small fringe might disappear, due to subsequent spreading of Phragmites. In abandoned parts of the "Nielönn" salt marsh on Sylt, Phragmites is spreading rapidly and has almost reached the edge of the marsh. For this area, Hueck (1934) took a photo of heavily-grazed marshes, showing a habitat identical with the marshes around Königshafen today.

Willows might establish when tidal salt water only occasionally floods this reed belt. But these "fringe type" reed belts on Sylt are very small, and regularly flooded in wintertime. Thus, willows will be able to establish occasionally; but this phenomenon may disappear when tidal floodings are too severe.

\section{Production and soil}

A direct effect of grazing is the removal of living and dead phytomass (Table 1). The ungrazed Halimionetum shows a considerably higher standing crop than the grazed Puccinellietum. Both are communities of the lower marsh. The range in standing crop is higher for grazed and ungrazed Puccinellia stands of the mainland marshes, and reaches from 280-1067 $\mathrm{g} / \mathrm{m}^{2}$ (Dierßen et al., 1991).

Standing crop (heavy/medium grazed sites) in the Puccinellietum is $8 \times$ (and in the Juncetum, $2 \times$ ) higher in clayey mainland marshes than in Königshafen. Organic matter is $3.5 \times$ higher $(3.7 \times)$ in the Puccinellietum (Juncetum) of Königshafen. Water content in the Puccinellietum is $1.6 \times$ (and in the Juncetum, $1.9 \times$ higher) in Königshafen.

Differences in production are marked, and may be related to higher clay content and better nitrogen availability at the mainland.

In order to give at least some basic information about soil characteristics, samples to a depth of $30 \mathrm{~cm}$ were taken and used for this descriptive and incomplete outline.

Salt marsh soils are expected to comprise a considerable amount of clay. The soil profiles in Königshafen, however, show a strong influence from the dunes. Only two small clay layers of 2 or $2.5 \mathrm{~cm}$ can be found in the upper $20 \mathrm{~cm}$ below large areas of the

Table 1. Standing crop, organic matter, and water content, in island and mainland salt marshes

\begin{tabular}{|c|c|c|c|}
\hline & $\begin{array}{l}\text { Standing crop } \\
\text { Dry weight }[g]\end{array}$ & $\begin{array}{c}\text { Organic matter AiGo-Layer } \\
\text { Loss on ignition [\%] }\end{array}$ & $\begin{array}{l}\text { Water content (Sept.) } \\
\% \text { Fresh weight }\end{array}$ \\
\hline $\begin{array}{l}\text { Puccinellietum, } \\
\text { Königshafen }\end{array}$ & $52 \pm 14$ & $28.6 \pm 0.5$ & $67.6 \pm 1.1$ \\
\hline $\begin{array}{l}\text { Puccinellietum, } \\
\text { Mainland }\end{array}$ & $429 \pm 25$ & $8.2^{*}$ & $40^{\cdots}$ \\
\hline $\begin{array}{l}\text { Juncetum, } \\
\text { Königshafen }\end{array}$ & $147 \pm 28$ & $26.3 \pm 1.3$ & $69.4 \pm 1.6$ \\
\hline $\begin{array}{l}\text { Juncetum, } \\
\text { Mainland }\end{array}$ & $320 \pm 9$ & $7.4^{\circ}$ & $37^{* *}$ \\
\hline $\begin{array}{l}\text { Halimionetum } \\
\text { Mainland }\end{array}$ & $1272 \pm 242$ & 5.8 & $34^{* *}$ \\
\hline
\end{tabular}


Puccinellia/Salicornia community. A thicker clay layer with blackish reduction marks stretches from $20-30 \mathrm{~cm}$. Close to the edge of the salt marsh (a distance of 5-10 m), upper sandy layers fade completely and the clay layer becomes thicker.

The major part of the soil profile consists of sand and sandy loam layers with a high humus content (Table 1). A high content of organic matter indicates high ground water tables preventing decomposition. A slightly increasing water content (September 1993: $60=>70 \%$ ) in the upper layers towards the marsh/dune transition in elevated sites indicates seepage from the dune area.

Although it is unusual to give figures for simple water content without any nutrient data, it is done here to demonstrate the difference from common mainland types: even water-saturated soil samples from the Puccinellietum at the mainland did not show higher contents than $40-50 \%$ fresh weight over five years (Körber \& Neuhaus, unpubl. report). The pore volume of peat, the soil with the highest content of organic matter, may reach $97 \%$, and the capacity to retain water is high (Schachtschabel et al., 1992). As the topsoil in the Königshafen salt marsh has a high content of organic matter, this should explain the high water content.

On the other hand, grazing destroys a considerable amount of soil pores in the upper layers via soil compaction, and promotes waterlogging (Jensen et al., 1990; Schachtschabel et al., 1992). As a consequence of a combination of grazing and the influence of groundwater seepage, salt marsh soils with a very high content of organic matter could develop. This stage of soil development resembles initial stages of peat formation.

\section{DUNES}

The current dune landscape of Sylt can be seen as a result of the processes during the last 400-500 years, after the last period of sand drift had started (Doody \& Skarregaard, 1991). A total of 2900 ha of dunes covers Sylt.

\section{Listland}

There is no beach plain on the exposed west coast, as there is on Amrum or Rømø, and storm floods usually erode the dune bases along the entire coastline every year. Thus, primary dunes built up by Elymus farctus are missing along the small shoreline. As a compensation measure to hold back blown sand, low fences from cut bushes are arranged in bands of rectangles at the dune base. As the cleaning activities of local authorities usually remove tidal litter from the shore, annual strandline plants can hardly establish.

Yellow dunes covered by Ammophila arenaria and large blow outs, together with older, partly overblown grey dunes, form a belt of $200 \mathrm{~m}$. Grey dune formation by grasses is partly suppressed, as the still mobile sand surfaces cannot be invaded by Corynephorus canescens, but are by Empetrum nigrum (Heykena, 1965). On the calm lee sides, and in small, dry slacks, initial stages of brownish dune heaths with Carex arenaria, Corynephorus canescens, Salix repens and Empetrum nigrum finally establish. The subsequent dunes are completely covered by dwarf shrubs like Empetrum nigrum and Calluna vulgaris (Heykena, 1965).

The plain, following the higher dunes at the coastline, is streaked with little dune 
ridges running from southeast to northwest. Exposed to salt spray, the shrub layer has gaps on top of the ridges, recovering with mosses and lichens.

In between, the dune slacks cover large areas. Erica tetralix as the dominant dwarf shrub species suffers from prolonged winter flooding. A regeneration cycle is initiated by Drosera rotundifolia and completed by Carex nigra, Carex panicea and Erica tetralix. Individuals of Erica tetralix in depressions are usually younger than those in elevated sites.

Turf cutting was practiced during World War II to gain fuel. Single slacks, where the soil surface was cut into deeply, were settled by rare species like Drosera rotundifolia, Lycopodiella inundata and Deschampsia setacea (Neuhaus, 1987).

After a certain period of sand accumulation ( \pm 300 years), the dune systems at the coastline are expected to reach a critical mass/threshold and shift from their building phase to a migratory phase (Priesmeier, 1970).

Three mobile dunes in the middle of the Listland area are left, which have not yet been seeded or planted. Other mobile dunes were planted in the 1930's, because they were about to bury the village of List (Müller, 1938). Kolumbe (1932) reported a large system of several kilometers of mobile dunes reaching from the Listland to the south.

Almost every old dune will be built into the large corps of the actively mobile dune system in the Listland, while moving towards north-eastern (main wind) direction with a variable speed of $2.5-8.5 \mathrm{~m} / \mathrm{a}$ (Neuhaus, 1990). On the luv side of mobile dunes, successional series of wet and dry heaths are reversed. Normally, successional stages are progressively older from the shoreline into the hinterland. The mobile dunes, however, create a new "shoreline" in the hinterland: easterly winds blow sand to the west and, with their reversed arrangement of successional stages, build up small, new dune systems as the mobile dune moves on.

Moving through the landscape, the mobile dune is blown out down to the groundwater at its lee side. The slacks are colonized by the Agrostis stolonifera-Juncus articulatusstage, followed by the Gymnocolea inflata-Zygogonium ericetorum-stage, during the first 6 years. The Erica tetralix-stage (Empetro-Ericetum Westhoff [1943] 1947) has become completely established after approximately 30 years (Neuhaus, 1990).

As a result of low nutrient status, calcium carbonate deficiency, salt spray, insufficient seed transport and land use, there are no dune shrubs or forests between the mobile dunes. Every now and then, Betula spp. try to establish, but the effect mainly of salt spray kills the plants after they grow up into the free space above the dwarf shrubs.

\section{Ellenbogen}

The "Ellenbogen" exhibits quite a different picture, especially the final stages. On its accreting northern coast (Fig. 2), there are beach plains and primary dunes formed by Elymus farctus (Elymo [arenariae-]Elymetum farcti Br.-Bl. \& De Leeuw 1936 emend. Tx 1957). Yellow and grey dunes form ridges parallel to the coastline, from west to east. As the wind erosion is not as strong, and formation of mobile dunes does not occur here, these older ridges can persist.

The yellow dunes are built up by Ammophila arenaria and Elymus arenarius (ElymoAmmophiletum Br.-Bl. \& De Leeuw 1936) with one of the last ocurrences of Calystegia soldanella in Schleswig-Holstein. The grey dunes are covered with the Festuco-Galietum 
veri (Onno 1933) Br.-Bl. et De Leeuw 1936, with moss and lichen layers as a consequence of sheep grazing. Empetrum nigrum and Calluna vulgaris rarely close the dwarf shrub layer, as they are susceptible to heavy grazing. Thus, the Ellenbogen lacks larger areas of dune heath. The primary dune slacks are too dry to carry a wet heath.

\section{NATURE CONSERVATION}

The entire Listland/Ellenbogen area has been protected by law since 1923. As a consequence of intensified land use, some controversial changes concerning status were established in 1980.

Generally, interactions of land-use (economic features) and landscape dynamics ("natural" features) should be focussed on objectives where the maintenance of essential characters of the protected landscape is guaranteed and, if possible, improved. The definitions of these characters will of course be crucial.

Humankind has changed the autonomy of many natural processes and is able to make processes (and plant communities) human-dependent. Results may sometimes look beautiful (and natural), as large heather-covered areas on the mainland show. In areas of nature protection, priorities for definitions of aims seem to be clear. Humankind's impact on the Listland/Ellenbogen area, however, is proven to have happened over hundreds of years, and it can neither be clearly assessed nor reversed by management. Thus, the guidelines for management of these areas have to be discussed in detail, and should be focussed on salt marshes, influenced by groundwater, and, to a lesser extent, on the dunes, because of the minor disturbance to the latter.

Land-use in the Listland/Ellenbogen area can be regarded in terms of building settlements, measures of coastal and dune protection, use of domestic stock, cutting, haymaking and tourism. Every impact effects a certain degree of displacement on the landscape, reaching from complete destruction of the surface and the plant communities (settlements), to negligible impact (slight grazing in large dune areas). In protected areas of the Listland/Ellenbogen we can focus on grazing, coastal protection and tourism. The impact of grazing on plant communities remains small in large dune areas of the Listland but is high on the Ellenbogen and on the salt marshes. The cessation of grazing will generally lead to conflicts with the economic interests of the land owners and communities; especially as a first step towards a "zero-use zone" (Reise, 1992).

After the cessation of grazing on the Ellenbogen, heath communities establish very slowly in exclosures, but a recovery with a shift to a Calluna/Empetrum-heath, as a final successional stage, seems to be possible. A "zero use" for the Ellenbogen should be pushed through in the long run, as mainly tourists use the dunes and the shoreline. Heavy dune erosion also seems likely to cut the Ellenbogen off from the Listland area in the near future. The Listland dune area mainly suffers from being trampled by tourists, but the essential character of the landscape is not affected.

The salt marsh concept seems to be more crucial. After the cessation of grazing in the salt marshes, the subsequent plant succession will not lead immediately to "natural" plant communities, as the salt marsh soils will probably never be able to start "natural" nutrient cycles due to irregular disturbances of the soil structure. Only the first successional stages will benefit from land use, and salt marsh species susceptible to grazing may invade the area. But they will represent only parts of the suppressed communities. 
Communities of the upper salt marsh and subsequently of the lower marsh will shift to Phragmites-dominated communities and probably disappear, as outlined above. Thus, management measures to keep these salt marshes always have to maintain a considerable grazing intensity. When discussing the outlines of a nature reserve, this should be questioned - the end result being an assessment of natural and anthropogenic influences.

Humankind's impact on sea level rise may first lead to a reduction of lower and subsequently of higher salt marshes. If the process of marsh erosion, which can be watched along most of the marsh edges (Ehlers, 1988), will decelerate to a point that accretion can at least balance it, and new salt marshes are in sight, local marshes may disappear and appear again in other places. Humankind's negative impact would then be partly balanced. The presumable time lag between the erosion of old, and the accretion of new marshes, will strongly depend on local sedimentation conditions and the availability of seed sources.

However, a realistic scenario will not predict a complete disappearance of salt marshes during the next years (Bakker et al., 1993), which is considered to be the only reason for maintaining grazing in remnant high marsh areas here. In this case, grazing would have a positive effect on the persistance of species from the Puccinellia communities at higher elevations (Raabe, 1965). Grazed salt marshes could serve as centres for the production of diaspores, although the floristic composition of grazed marshes is greatly impoverished by grazing.

Thus, grazing is considered to be an inadequate tool to retain salt marshes and may be used only on very limited conditions, as outlined above. This "hierarchical" decision considers major threats as prior to minor ones on the marshes, and will neither accept a general disappearence of salt marsh communities from the coastline, nor a grazing regime keeping up an artificial diversity. Natural processes should govern the scene as far as possible.

Alternative concepts regarding grazing as a measure of "culture protection" are not considered here. A prediction of the accretion/erosion regime on the local scale seems necessary to evaluate the future of salt marshes and coastlines in different regions of the Wadden Sea. Further discussions about the management of salt marshes are part of the current debate of the national park authority in Schleswig-Holstein.

\section{FLORISTIC SURVEYS}

Botanists of the 19th and 20th centuries, such as Buchenau (1887), Knuth (1890), Raunkiaer (1890), Reinke (1903) and Christiansen (1928) visited Sylt - being mainly interested in floristic questions, species/area relations and life forms. Reinke (1903), Nienburg (1927), Kolumbe (1943), Hobohm (1986) and, in particular, Heykena (1965) gave deeper insights into successional stages of dunes and/or salt marshes and their occurrence on Sylt.

Acknowledgements. I would like to thank T. Stelter for careful digitizing, K. Kiehl, K. Dierßen, E. Aegerter and J. Bakker for helpful comments on the manuscript. D. Tannheiser and K. Dijkema gave useful remarks in their reviews. 


\section{LITERATURE CITED}

Adam, P., 1990. Saltmarsh ecology. Cambridge Univ. Press., Cambridge, 460 pp.

Ahrendt, K., 1993. Sedimentdynamik an der Westküste Sylts (Deutsche Bucht/Nordsee). - Meyniana $45,161-179$.

Armstrong, W., Wright, E. J., Lythe, S. \& Gaynard, T. J., 1985. Plant zonation and the effects of the spring-neap tidal cycle on soil-aeration in a Humber salt marsh. - J. Ecol. 73, 323-339.

Bakker, J., 1990. Effects of grazing and hay-making on Wadden Sea saltmarshes. In: Saltmarsh management in the Wadden Sea Region. Ed. by C. H. Ovesen. Ministry of the Environment, The National Forest and Nature Agency, Viborg, 51-65.

Bakker, J. P. \& Ruyter, J. C., 1981. Effects of five years of grazing on a salt-marsh vegetation. Vegetatio $44,81-100$.

Bakker, J. P., Leeuw, J. de, Dijkema, K. S., Leendertse, P. C., Prins, H. H. T. \& Roizema, J., 1993. Salt marshes along the coast of the Netherlands. - Hydrobiologia 265, 73-95.

Bantelmann, A., 1966. Die Landschaftsentwicklung an der schleswig-holsteinischen Westküste, dargestellt am Beispiel Nordfriesland. - Küste 14 (2), 5-99.

Beeftink, W. G., 1977. The coastal salt marshes of western and northern Europe: an ecological and phytosociological approach. In: Wet coastal ecosystems. Ed. by D. W. Goodall. Elsevier, Amsterdam, 109-155.

Buchenau, F., 1887. Vergleich der nordfriesischen Inseln mit den ostfriesischen in floristischer Beziehung. - Abh. naturw. Ver. Bremen 9, 361-384.

Buchwald, K., 1966. Die Bedeutung des Naturschutzgebietes Nord-Sylt für Forschung und Lehre. SchrReihe dt. Rat Landespflege 6, 24-27.

Chapman, V. J., 1976. Coastal vegetation. Pergamon Press, Frankfurt, 292 pp.

Cooper, A., 1982. The effects of salinity and waterlogging on the growth and cation uptake of salt marsh plants. - New Phytol, 90, 263-275.

Christiansen, D. N., 1928. Neues zur Flora von Sylt. - Jb. naturw. Ver. Altona 1928, 1-5.

Christiansen, J., 1923. Zur Agrargeschichte der Insel Sylt. - Arch. Beitr. dt.-schweiz.-skand. Privatrecht $2,5-49$.

Dierßen, K., 1988. Rote Liste der Pflanzengesellschaften Schleswig-Holsteins. - SchrReihe Landesamt Naturschutz Landschaftspflege Schlesw.-Holst. 6, $159 \mathrm{pp}$.

Dierßen, K., Eischeid, I., Härdtle, W., Hagge, H., Hamann, U., Kiehl, K., Körber, P., Lütke Twenhöven, F., Neuhaus, R. \& Walter, J., 1991. Geobotanische Untersuchungen an den Küsten Schleswig-Holsteins. - Ber. Reinh.-Tüxen-Ges. 3, 129-155.

Diggelen, J. van, 1988. A comparative study on the ecophysiology of salt marsh halophytes. Free Univ. Press, Amsterdam, 208 pp.

Dijkema, K., 1987. Geography of salt marshes in Europe. - Z. Geomorph. 31, 489-499.

Dijkema, K., Beeftink, W. G., Doody, J. P., Gehu, J. M., Heydemann, B. \& Rivas Martinez, S., 1984. Salt marshes in Europe. Council of Europe, Strasbourg, $175 \mathrm{pp}$.

Doody, P. \& Skarregard, P., 1991..Denmark. In: Sand dune inventory of Europe. Ed. by J. P. Doody. Joint Nature Conservation Committee, Peterborough, 21-23.

Ehlers, J. J., 1988. Morphologische Veränderungen auf der Wattseite der Barriere-Inseln des Wattenmeeres. - Küste 47, 3-30.

Fischer, O., 1955. Hydrographie des Küstengebietes. In: Das Wasserwesen an der schleswigholsteinischen Nordseeküste. III: Das Festland. Hrsg. von F. Müller \& O. Fischer. Reimer, Berlin, $314 \mathrm{pp}$.

Glahn, H. v., Dahmen, R., Lemm, R. v. \& Wolff, D., 1989. Vegetationssystematische Untersuchungen und großmaßstäbliche Vegetationskartierungen in den Außengroden der niedersächsischen Nordseeküste. - Drosera 89, 145-168.

Gray, A. \& Scott, R., 1977. Biological flora of the British Isles: Puccinellia maritima. - J. Ecol. 65, 699-716.

Heykena, A., 1965. Vegetationstypen der Küstendünen an der östlichen und südlichen Nordsee. Mitt. AG Floristik Schlesw.-Holst./Hamb. 13, 1-135.

Hobohm, C., 1986. Die Salzwiesen von Sylt. - Kiel. Notizen 18, 57-99.

Hueck, K., 1934. Dünen, Sandfelder, Salzpflanzen, Steppenheiden, alpine Vegetation. In: Pflanzenwelt der deutschen Heimat und der angrenzenden Gebiete. Hrsg. von K. Hueck. Bermühler, Berlin, $240 \mathrm{pp}$. 
Jensen, A., 1985. The effect of cattle and sheep grazing on salt marsh-vegetation at Skallingen, Denmark. - Vegetatio 60, 37-48.

Jensen, A., Skovhus, K. \& Svendsen, A., 1990. Effects of grazing by domestic animals on saltmarsh vegetation and soils, a mechanistic approach. In: Saltmarsh management in the Wadden Sea Region. Ed. by C. H. Ovesen. Ministry of the Environment, The National Forest and Nature Agency, Viborg, 153-161.

Jong, J. de, Kers, B., Esselink, P., Bakker, M. de \& Dijkema, K., 1993. Vegetatieontwikkeling in de Dollard na het instellen van extensief beheer. - Levende Natuur 94, 176-182.

Knuth, P., 1890. Botanische Wanderungen auf der Insel Sylt. Dröhse, Tondern, 116 pp.

Kolumbe, E., 1932. Ein Beitrag zur Entwicklungsgeschichte des Könighafens bei List auf Sylt. Wiss. Meeresunters. (Kiel) 21, 117-130.

Kolumbe, E., 1943. Über die Entwicklung einiger Dünenkleinformen auf Sylt. - Z. Geschiebeforsch. Flachldgeol. 18, 116-125.

Müller, F., 1938. Sylt. In: Das Wasserwesen an der schleswig-holsteinischen Nordseeküste. II: Die Inseln. Hrsg. von F. Müller \& O. Fischer. Reimer, Berlin, 304 pp.

Müller, F. \& Fischer, O., 1956. Eiderstedt. In: Das Wasserwesen an der schleswig-holsteinischen Nordseeküste. III. Das Festland. Hrsg. von F. Müller \& O. Fischer. Reimer, Berlin, 328 pp.

Neuhaus, R., 1987. Vegetationskundliche Untersuchungen der Feuchtheiden in Dünentälern (Nordfriesische Inseln). Examensarb., Univ. Kiel, 72 pp.

Neuhaus, R., 1990. Stadien und Alter der Primärsukzession von Feuchtheiden in Küstendünen. Drosera 90, 29-34.

Nienburg, W., 1927. Zur Ökologie der Flora des Wattenmeeres. - Wiss. Meeresunters. (Kiel) 20, $67-72$.

Oberdorfer, E., 1983. Pflanzensoziologische Exkursionsflora. Stuttgart, Ulmer, 1051 pp.

Priesmeier, K., 1970. Form und Genese der Dünen des Listlandes auf Sylt. - Schr. naturw. Ver. Schlesw.-Holst. 40, 11-51.

Raabe, E. W., 1965. Sukzessionsstudien an Salzrasen. - Heimat 72, 3-7.

Raabe, E. W., 1981. Über das Vorland der östlichen Nordseeküste. - Mitt. AG Geobot. Schlesw.Holst./Hamb. 31, 1-118.

Raunkiaer, C., 1890. Notes on the vegetation of the North-Frisian islands and a contribution to an eventual flora of these islands. - Bot. Tidsskr. 17, 179-196.

Reichstein, J., 1990. Insel im Wandel seit 8000 Jahren. - Archäol. Deutschld 90, 20-27.

Reinke, K., 1903. Botanisch-geologische Streifzüge an den Küsten des Herzogtums Schleswig. Wiss. Meeresunters. (Kiel) 8 (Erg.-H.), 1-157.

Reise, K., 1992. The Wadden Sea as a pristine nature reserve. - Publ. Ser. Neth. Inst. Sea Res. 20 49-53.

Schachtschabel, P., Blume, H. P., Brümmer, G., Hartge, K. H. \& Schwertmann, U., 1992. Lehrbuch der Bodenkunde. Enke, Stuttgart, 491 pp.

Scherfose, V., 1986. Pflanzensoziologische und ökologische Untersuchungen in Salzrasen der Nordseeinsel Spiekeroog. I. Die Pflanzengesellschaften. - Tuexenia 6, 219-248.

Straka, G. \& Straka, H., 1984. Über die Veränderungen der Vegetation im nördlichen Teil der Insel Sylt (NSG Nord-Sylt) von 1960 bis 1982. - Schr. naturw. Ver. Schlesw.-Holst. 54, 1-17.

Tuisel, V., 1983. Vegetationskundliche Untersuchungen der Salzwiesen nördlich List/Sylt. Examensarb., Univ. Kiel, 65 pp.

Westhoff, V., 1987. Salt marsh communities of three West Frisian islands, with some notes on their long-term succession during half a century. In: Vegetation between land and sea. Ed. by A. H. L. Huiskes, C. W. P. M. Blom \& J. Rozema. Junk, Dordrecht, 16-40.

Wohlenberg, E., 1937. Die Wattenmeer-Lebensgemeinschaften im Königshafen von Sylt. - Helgoländer wiss. Meeresunters. 1, 1-92. 